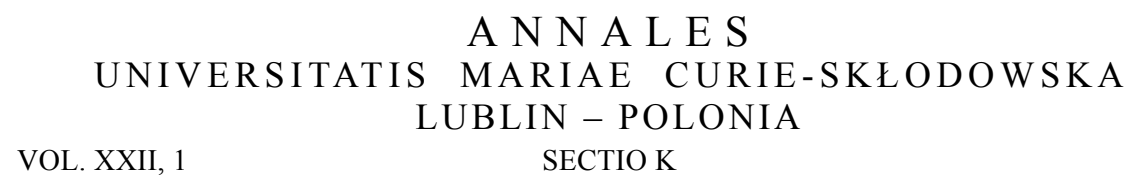

A N N A L E S

UNIVERSITATIS MARIAE CURIE-SKŁODOWSKA LUBLIN - POLONIA

VOL. XXII, 1

SECTIO K

Interdisciplinary Humanistic Doctoral Studies,

Faculty of Philosophy and History, University of Łódź, Poland

\author{
OLGA BOGDAŃSKA
}

\title{
Libel tourism in the context of press freedom
}

\begin{abstract}
The phrase 'libel tourism' appeared for the first time in 1990, when a Hollywood star Arnold Schwarzenegger sued American author Wendy Leigh for his unauthorized biography in an English court [Rayner 2010; Sanchez 2011]. A number of recent cases included wealthy libel tourists such as Nicole Kidman, David Hasselhoff, Roman Polański, Jennifer Lopez, Marc Anthony, Britney Spears, Tiger Woods and Cameron Diaz. Since 2005, the number of libel actions in the High Court has doubled, and in 2009, there were 219 defamation cases issued; 34 of them were identified as having a "foreign connection" [Ministry of Justice, Report of the Libel Working Group]. In a short time, the widespread opinion has appeared that London has become the "Libel Capital of the World" [London "The Times", Be Reasonable; Carvajal, Britain, a Destination for 'Libel Tourism']. Through an extensive review of relevant case law and studies I would like to draw attention to the problem of libel tourism which creates a chilling effect on press freedom.
\end{abstract}

Key words: chilling effect, defamation law, freedom of expression, libel tourism

The definition of 'libel tourism' is complex to characterize, although the general view of this approach is that the term is used to describe a phenomenon of filing a lawsuit in libel cases by the suing party away from his/her place of residence due to a better chance of getting a good result [Staveley-O'Carroll 2009; Sanchez 2011]. It allows avoiding restrictions in the legal system of the claimants' home country. In 2010, the United Kingdom's Ministry of Justice established the Libel Working Group to consider reforms to the law of libel. In their special report, the term 'libel tourism' was further explained as it [qtd. in the Ministry of Justice, Report of the Libel Working Group: 4]: 
usually involves the situation where a person from outside England and Wales ${ }^{1}$ issues proceedings in a court of England and Wales in order to sue another person from outside England and Wales. Additional factor may involve the extent to which parties are connected to England and Wales for example, whether the claimant has a reputation which is particular to England and Wales; the extent of the defendant's relationship to this jurisdiction compared with elsewhere; where the allegedly defamatory material is primarily published and targeted at; and extent of publication in this jurisdiction compared with elsewhere.

This in fact leads to the quiet suppression of freedom of expression. Taking into consideration the importance of freedom of press in democratic society, libel tourism has become a subject of intense discussion particularly in the United Kingdom, the United States and in the European Union. In order to prevent spreading the above phenomenon, propositions of changes concerning a reform of defamation law have been presented.

The main objective is to contribute to a more thorough discussion on civil defamation law and its excessive chilling effect on freedom of expression. This topic has already raised a lot of interest, but still, current European studies seem to limit their focus on criminal defamation laws and their civil counterparts have been hardly acknowledged in academic accounts. Therefore, this article addresses the long history of conflict between freedom of speech and the right of citizens to protection from libel. The main problem arises when the defamation law strikes a fair balance between personal right to reputation and the right to freedom of expression [Smet 2010]. I am interested in examining the defamation law in England, which for many years was said to be in conflict with media's right to freedom of expression [Bennett 2010: 3]. ${ }^{2}$

There is of course no denial for the importance to individuals of their reputations, but it is just crucial in some cases to become more restrictive for non-residents to sue foreign-based publications for defamation in the English courts. The article further aims at developing this argument by the analysis of the previous defamation law in England (reformed to some degree in 2014) and the outline why it should have been changed in the interests of media freedom of expression. I will also indicate the strengths and weaknesses of the various remedies that were presented to overcome the problem of "libel tourism".

1 The term "English law" is a mental shortcut. The UK consists of three separate jurisdictions: England and Wales, Scotland and Northern Ireland. References to "English" and "England" for sake of simplicity relate equally to England and Wales but do not relate to Scotland, where here are some differences in the Law. References to the "United Kingdom" relate to England, Wales, and Scotland.

2 Recently, there have been a number of changes in defamation law under a Defamation Act 2013, which finally came into force on January 1, 2014. 


\section{LIBEL CAPITAL OF THE WORLD}

People often choose England of which jurisdiction in libel cases is perceived as more pro-plaintiff, and therefore, those libeled take advantage of this situation to sue for defamation in England, rather than in any other country. Indeed, there are several aspects whose combined effect has solidified the English reputation as one of the most favored places to bring a libel lawsuit. These pro-plaintiff features of English law include: burden of proof, fee-shifting provision and the so-called "multiple publication rule" [Sanchez 2011].

\section{BURDEN OF PROOF}

Firstly, I would like to draw attention to the legal obligation called burden of proving truth of allegations that is considered to be one of the factors that has created the reason to file suits in England. Significantly, shifting the burden of proof under English law remains on the defendant who is required to prove that a defamatory statement was "true or substantially true" [House of Commons, Press standards, privacy and libel]. In other words, every critical opinion filed to English court is treated as untrue. Even when an allegation is correct, it can be difficult or even impossible to discharge. According to the $18^{\text {th }}$-century English proverb: "the greater the truth, the greater the libel", which still seems to be actual [Watrous 1899: 4].

Problems with the burden of proof being placed on the defendant arise from a number of recent cases. These can be illustrated for example with the Liberace v. Daily Mirror Newspaper libel case from 1956. Action was brought against the Daily Mirror article that insinuated that Liberace (1919-1987), a famous American showman and pianist, was homosexual. Liberace denied his homosexuality and won the suit, because the defendant did not hand over evidence to prove the published allegation and to successfully confirm the truth [Greenslade 2009]. But after Liberace's death, it was discovered that, indeed, he was homosexual and had a five-year relationship with Scott Thorson [CNN Larry King Live].

Another famous case, analyzed in this context, is Steel v. McDonald's, better known as the McLibel Trial. Helen Steel and David Morris, members of "London Greenpeace," published the leaflet entitled "What's Wrong with McDonald's?" that provoked the defamation suit. It was suggested that the defendants' defense led to failure, because they were not able to satisfy the burden of proof. In the light of the result, appellants argued that England should break off with this norm and in defamation actions allocate the burden of proof on plaintiff's side. On the other hand, the respondents submitted that in English law it is clear that a plaintiff who establishes that a publication is defamatory of him does not have to prove that the words complained of are false [Steel $v$. McDonald (2006)]. This has been expressed in numerous judgments as "(...) a libel prima facie imports a wrong, which it could 
not do if the alleged libelous matter were true, and therefore the onus of proving the truth thereof is cast on the defendant" [Belt v. Lawes (1882)] and "the defendant in his statement of defense traverses the falsehood of the statement alleged to have been made by him, and thereby takes the onus of justifying, but this he would have without such traverse" [Belt v. Lawes (1882)].

English rule was unfavorable for press organs. It is the accused journalist who, in order to win a lawsuit, must prove the statement he/she published are true [Philadelphia Newspapers Inc v. Hepps (1986)]. It makes much easier for the aggrieved party to settle any claim. What is more, the English rule on the burden of proof stays contrary to a presumption of innocence principle and infringes the right of journalist to protect the identity of confidential sources. Therefore, due to the informers' risk of being revealed, journalists might face the problem to obtain from them crucial information. This has significant implications on the ability of journalists to perform their "watchdog" function on behalf of the public.

\section{FEE-SHIFTING PROVISION}

To continue, as a general rule in defamation claims brought in England, the losing party is required to pay the winning party's costs [Sanchez 2011: 484]. The English fee-shifting model was designed in order to fulfill the libel law's key goal to keep the balance between protecting reputations and encouraging free speech. For example, a threat of the potential burden of bearing the defendant's litigation costs ought to discourage potential claimants from filling "non-meritorious lawsuits" [Windon 2010]. Moreover, the claimant can hire lawyers under Conditional Fee Agreements (CFAs), commonly known as "no win no fee" arrangements, which were introduced in 2000 and were structured in order to facilitate the access to justice for individuals who cannot afford legal fees. Essentially, legal fees and expenses only become payable if the lawsuit is successful. As a result, entering into a CFA usually means that higher rates are charged in order to accept a case, but the obvious advantage in this situation is that if a plaintiff wins the case, all costs are recoverable from the other party.

Ironically, the English "loser pays" rule and "no win no fee" cause that the plaintiff has an incentive to bring the claim in England [Staveley-O'Carroll 2009: 259]. The reason lies in the unfairly biased defamation law. Study results indicate that $90 \%$ of libel suits in England and Wales are won by the claimant [Abrams 2009]. In practice it means that usually the defendant is entitled to recover attorney's fees incurred in connection with an action.

In some cases, legal actions concerning alleged libel are taken only in order to intimidate or make a defendant bankrupt. It is estimated that judicial and legal costs in England are higher than in other European countries. Two free expression organizations, English Pen and Index on Censorship, checked that "defending a libel 
action in English law is 140 times more expensive than elsewhere in Europe" [Index on Censorship/English Pen, Parliamentary Briefing...].

Moreover, regarding the financial side of a defamation suit, we cannot forget that most claimants will be seeking compensation for damage to their reputation as a result of a defamatory statement. Covering awarded damages to the winning party additionally increases the cost involved in a defamation to the unsuccessful defendant. First of all, due to the fact that the jury determines the amount of damages, awards are usually excessively high [Slapper and Kelly 2011: 491]. In the 1980s, a huge controversy arose that such a situation could restrict the free flow of information and discourage authors from publishing freely due to a fear of sanctions. Therefore, Parliament passed the Courts and Legal Service Act which, under section 8, "Powers of Court of Appeal to award damages", empowered the Court of Appeal to change a previously established award as follows [qtd. in Courts and Legal Services Act 1990]: “(1) In this section 'case' means any case where the Court of Appeal has power to order a new trial on the ground that damages awarded by a jury are excessive or inadequate".

According to Staveley-O'Carroll, the majority of libel cases defendants still cannot afford to defend themselves and to pay the sanctions [2009: 259]. Understandably, due to the risk of high compensation on account of libel, many sued journalists decide to reach a settlement, despite the fact that their texts are true in $100 \%$. Moreover, some journalists may simply avoid delicate issues - in this way, according to the Index on Censorship - freedom of press is censored. There is no denial of the need for remedies for defamatory statements; however, the level of compensation should be limited as necessary to reward the harm done to a claimant's reputation without having a chilling effect on freedom of expression. I continue to believe that the legal fees applied in the UK are drastically high compared to legal fees in other countries, and they require urgent reform. For this reason it is proposed to conduct a study on the effectiveness, utility, and impact of launching new sanctions.

\section{"MULTIPLE PUBLICATION RULE"}

Since 2014, there has also been one more serious problem in regulations concerning the statute of limitations of libel claims that encouraged foreigners to bring libel suits in England. Namely, they could take advantage of the court decision in favor of which established the precedent called "multiple publication rule". ${ }^{3}$ Courts in England cited Victorian rule from a case Duke of Brunswick in 1849, which says

3 The English law of defamation was considered as one of the most obsolete laws in the world [Williams 1997: 107]. 
that each re-edition of an article that includes libel is a separate reason to take legal actions. $^{4}$

This rule was further approved by the Court of Appeal in a libel litigation between Grigori Loutchansky and "The Times" newspaper. Loutchansky, a Russian businessman, brought proceedings for libel against two articles published by "The Times" in 1999. The first action was in relation to the article in the newspaper and the second was brought in respect to the article remained on the newspaper's website [Dunlop, Case analysis]. Relying in particular on the authority of the rule in the Duke of Brunswick's case, the Court of Appeal held that [in Loutchansky v. Times Newspapers Ltd (2001)]: "It is a well established principle of the English law of defamation that each individual publication of a libel gives rise to a separate cause of action, subject to its own limitation period".

The rule of "multiple publication" has been the subject of much criticism by the Court of Human Rights in the Loutchansky case (2001). It stressed that it was a violation in the context of Article 10 of the European Convention on Human Rights. Recently, growing number of online editions of newspapers additionally complicated a situation. Each text on the website may cause, as a result, initiating next proceedings.

In the era of the Internet, there has been a strong impetus in favor of reform of this Victorian-era rule. Currently, the first text publication is treated as a moment when statute of limitations begins. What is more, it allows the aggrieved party to initiate only one proceeding in order to get compensation for a defaming press publication [Sanchez 2001: 501]. It is an original publication, and not its circulation that is subject to claim.

\section{INTERNATIONAL LIBELS}

International Libels relates to answering the question: "How can a foreigner bring a libel action to England against the infringer?" Therefore, Private International Law, also known as Conflict of Laws, becomes relevant to resolving this issue [Collier 2001: 3]. Since the decision in Kroch v. Rossell from 1937, in order to determine whether the English court is correct to assume jurisdiction over a defendant not domiciled in England, a forum test must be applied by checking that "a real and substantial connection" with a chosen forum for action exists [Kroch v. Rossell (1937)].

4 In 1830, an article which was published in the "Weekly Dispatch" defamed the Duke of Brunswick. After seventeen years, the Duke's manservant obtained a back number of publications from the British Museum and the newspaper's publisher's office. At that time, the limitation period for bringing a libel case for legal proceedings was six years. Although the cause of action was time-barred, the Court decided that the delivery of a copy of the newspaper constituted a separate cause of action [Duke of Brunswick v. Harmer (1849)].

5 "Conflict of laws" is the term used in the United States, Canada and England, while the continental countries refer to "Private International Law" [Scoles and Hay 1]. 
However, under the doctrine forum non conveniens, the English court may rule that there is elsewhere a more appropriate jurisdiction where the case ought properly to be tried [in Berezovsky v. Michaels (2000)]:

There is, so to speak, a jungle of separate, broadly based, jurisdictions all over the world. In England, for example, jurisdiction is founded on the presence of the defendant within the jurisdiction, and in certain specified (but widely drawn) circumstances on a power to serve the defendant with process outside the jurisdiction. But the potential excesses of common law jurisdictions are generally curtailed by the adoption of the principle of forum non conveniens - a self-denying ordinance under which the court will stay (or dismiss) proceedings in favor of another clearly more appropriate forum.

The guidelines to establish whether a court is suitable or appropriate for the trial of the action exists in the leading cases, such as The Atlantic Star (1974), MacShannon v. Rockware Glass Ltd (1986), Trendtex Trading Corporation v. Credit Suisse (1989) and in The Abidin Daver (1984). The main goal is to prevent "forum-shopping" claimants from pursuing claims inappropriately before the English courts. Nevertheless, the situation in the United Kingdom shows that this country has generally been extremely generous to accept libel suits from defendants outside England and Wales.

For example, the forum test was followed in the Berezovsky case [Taylor 2010]. In 1996, the influential American magazine, "Forbes", published a story about the Russia's oligarchs, Boris Berezovsky and Nikolai Glouchkov. It was introduced with a headline that read: "Is he the Godfather of the Kremlin? Power, Politics, Murder. Boris Berezovsky can teach the guys in Sicily a thing or two" [Godfather of the Kremlin?]. According to the article, Berezovsky and Glouchkov were "criminals on an outrageous scale". Furthermore, Berozovsky was introduced as a "powerful gangland boss" and it was even strongly suggested that he was implicated in the murder of Vladislav Listyev, the Russian television journalist and top official at Russian Public Television.

After this publication, Boris Berezovsky also brought a libel case against American magazine in London. A few copies of newspaper (about 6,000) sold were enough to sue a publication in the English court [Berezovsky v. Michaeals (2000)]. Moreover, the House of Lords, in a 3 to 2 decision on November 19, 1998, ruled that Berezovsky had "a substantial connection" with the United Kingdom [Berezovsky v. Michaels (2000)]. According to the case files, it was found that he frequently visited London for business purposes, he had an apartment there, and his two daughters were studying at Cambridge University [Berezovsky v. Michaels (2000)]. The overall opinion about this ruling was negative.

After the Berezovsky case, the forum test has rightly been criticized as being too "anachronistic" in a globalized world. It has been argued that more and more litigants take advantage of the global publication of magazines which are beyond 
national and jurisdictional boundaries [Partlett and McDonald 490]. In this situation the claimant is allowed to sue for libel in every country where the publication is distributed, which truly gives a wide choice of forums.

In the European Union, rules on international jurisdiction among member states are regulated by the Brussels Convention on Jurisdiction and the Enforcement of Judgments in Civil and Commercial Matters of 1968, which became part of English law under the Civil Jurisdiction and Judgments Act in 1982. Under its general rule (Article 5 No. 3) a defendant can be sued: "(...) in the Courts of the place where the harmful event occurred or may occur" [in EC Convention on Jurisdiction and the Enforcement of Judgments in Civil and Commercial Matters 1968]. In other words, English courts can still remain appropriate for action in the situation when neither the plaintiff nor defendant resides in the forum, but they are domiciled in a member state. This option poses a serious problem for trans-frontier media organizations which can be sued in as many places as their service can be received. It was confirmed by the European Court of Justice in Shevill v. Presse Alliance SA that [Shevill v. Presse Alliance SA (1995)]:

the victim of a libel by a newspaper article distributed in several Contracting States may bring an action for damages against the publisher either before the courts of the Contracting State of the place where the publisher of the defamatory publication is established, which have jurisdiction to award damages for all the harm caused by the defamation, or before the courts of each Contracting State in which the publication was distributed and where the victim claims to have suffered injury to his reputation, which have jurisdiction to rule solely in respect of the harm caused in the State of the court seized.

This ruling might be problematic in relation to international figures, celebrities, and business people who enjoy cross-border reputations and could be a danger to freedom of expression. In such cases of international distribution of media products, the plaintiff can choose between several courts in different countries and thus has the possibility to take advantage of "forum shopping".

An example occurred in the Polański case from 2002, where Condé Nast Publications Ltd, which is an American publisher of the magazine "Vanity Fair", appealed a $£ 50,000$ [Conzes 2005; Sanchez 2011] damage award in a libel suit brought by the Polish film director Roman Polański. This libel case referred to an article published in the July 2002 edition of "Vanity Fair". Polański brought this action to the High Court in London, even though the plaintiffs' connection to the forum was tenuous. Roman Polański could not even come to England to give evidence, due to the risk of being extradited to the United States, where he was accused of having sex with a 13-year-old girl [Conzes 2005; Sanchez 2011].

In this case, the Lord of Appeal in Ordinary, Lord Nicholls, gave an opinion that "Mr. Polański's reputation is international" [Polanski v. Condé Nast Publications Ltd. (2003)], overtly stating that this entitled him to bring libel action in England. This 
decision established a precedent which, in recent years, has resulted in the practice of shopping for a favorable jurisdiction by Hollywood-affiliated actors and opened the door for other celebrities with international reputation to choose an English court for libel suits.

\section{LIBEL TOURISM}

Why is libel tourism a problem? Is it really a big threat? As mentioned in the previous chapter, English legal system fails to give sufficient weight to the right to freedom of expression and the countervailing protection of reputation, hence, it provides rich, famous and powerful people with the tool that can easily silence journalists. Maintaining such situation can create the so-called chilling effect.

This term refers to the threat to freedom of speech caused by unnecessary restrictions apart from legal restrictions [Schauer 1978: 687]. The expression was introduced by the U.S. Supreme Court in Dombrowski v. Pfister noting that: "The chilling effect upon the exercise of First Amendment rights may derive from the fact of the prosecution, unaffected by the prospects of its success or failure" [Dombrowski v. Pfister (1965)]. Since its debut, most frequently the chilling effect concept has been used to describe an "inhibition of the freedom of expression" [Shapiro 2006: 102]. Freedom of speech is considered chilled when journalists and publishers are deterred from publishing their certain works.

The basis of this avoidance is mostly a fear of punishment. Defamation in many European countries, such as Austria, Belgium, Denmark, Italy, Poland or Norway, is still treated as a crime, punishable even by imprisonment [White 2008: 134]. For many years, the International Federation of Journalists, the world's largest organization of journalists, has been calling for a global ban on the use of criminal law against media. The trend towards decriminalization was visible in the United Kingdom in 2009, when the introduction of the Coroners and Justice Act finally abolished defamation as a criminal offence, and instead dealt with it in civil law courts [Coroners and Justice Act 2009]. Even if rarely used in democratic countries, punitive fines still exist as the most serious threats to press freedom.

But journalistic environment claims that draconian defamation laws of a civil nature are a manifestation of suppressing justified social criticism and can also be misused to censor criticism and debate concerning public issues. Equally troubling is the high costs of civil litigating occurs in English jurisdiction where libel is described as a "rich man's law" [Owen 2001: 130]. Indeed, improper and harsh sanctions, or even the threat of such sanctions, has a destructive effect on journalists.

Meanwhile, libel judgments have other various consequences that may influence the free speech. As a result of the level of costs in defamation proceedings, in order to minimize the risk of expensive litigation, journalists and publishers can either withhold publication of the papers in the territory of England or self-censor them. 
Indeed, this forced behaviour is an indication of libel tourism. Claimants are genuinely concerned less about monetary recovery than revenge on media who bruise their egos [White 2008: 134]. What is notable about many libel actions is that they appear to be brought by foreign claimants not to collect damages, but to frighten the press and critics - to achieve political ends, deter investigation, and suppress discussion of public issues [Berezovsky v. Michaels (2000)].

Billionaires from Middle East countries and Russian oligarchs are keen on bringing libel lawsuit against their American critics in England. For example, English courts pronounced at least twenty-nine times in the cases of a Saudi banker, Khalid Bin Mahfouz. He was a notorious "libel tourist", instead of trying to enforce the British court order, maintained a web site describing his defamation challenges [Bin Mahfouz...].

A number of leading newspapers, including "USA Today", "The Sunday Independent", "The Wall Street Journal", and "The Los Angeles Times", were obliged to publish apologies regarding articles which referred to Bin Mahfouz and his links with al-Qaeda. In general, he has secured forty eight "corrections". The reason of lawsuit was, among others, a book entitled Funding Evil: How Terrorism is Financed and How to Stop It published in 2003 by an American publishing house, Bonus Book Inc., in which Dr. Rachel Ehrenfeld wrote that Mahfouz financed al-Qaeda via his bank and charity organization [Klein 2010: 106]. After that case, journalists have quickly acknowledged that by writing about the Saudi billionaire they expose themselves to a potential libel suit in England even when there is a lack of a real connection with the forum - the potential effect in this situation was the elimination of investigative journalism.

According to the U.N. Human Rights Committee, English libel laws "served to discourage critical media about publishing matters on global concern - especially subjects related to international finance, global terrorism, celebrities, and any other high-profile figures - they warn them of liability abroad" [U.S. Congress, Securing the Protection of Our Enduring and Established Constitutional Heritage Act]. It is an affront to free speech. Certainly free press in democratic countries should act as a "watchdog" and without hindrance inform the public about wrongdoing. The phenomenon of libel tourism chills the exercise of the media's right to freedom of expression by making journalists afraid to tackle issues of public importance or to write about people with a reputation of being a 'libel tourist' [Taylor 2010]. It may prompt self-censorship and, therefore, constitute irreparable damage to the free flow of ideas. For example, due to threats of legal proceedings in relation to the reputation infringement, large publications such as "Time", "Newsweek", and "USA Today" have already published separate editions for the British market which comply with restrictive libel laws [Taylor 2010: 203].

Moreover, after Sheikh Mahfouz threatened to sue in England Random House over publication of Craig Unger's book House of Bush, House of Saud and Cambridge University Press of J. Millard Burr and Robert O. Collins's book Alms for Jihad, publishers were motivated to cancel publication there [Ehrenfeld v. Mahfouz 
(2005), Sanchez 2011:487]. Similarly, due to libel risks, the foreign publishers considered withholding sales of their titles in the UK and blocking access to their websites. "The Boston Globe", "The New York Times", and "The Los Angeles Times" have signed a joint statement to the House of Commons' Media Select Committee warning that [in Memorandum]:

Leading US newspapers are actively considering abandoning the supply of the 200-odd copies they make available for sale in London - mainly to Americans who want full details of their local news and sport. They do not make profits out of these minimal and casual sales and they can no longer risk losing millions of dollars in a libel action which they would never face under US law. Does the UK really want to be seen as the only country in Europe - indeed in the world - where important US papers cannot be obtained in print form?

The phenomenon serves to chill press freedom, notwithstanding that a relatively small number of cases reach court. Reason of concern about libel tourism is that plaintiff-friendly English libel laws have imposed major restrictions on free speech around the world. This has not only affected English journalists, but also impacted on international media. English libel judgments have the potential to chill speech in the United States and European democracies which developed libel regulations favourable for a defendant and limits of freedom of speech are broader than in a traditional English approach.

\section{LIBEL LAW REFORM: THE CHALLENGE}

Therefore, there was a growing focus on defamation law reform. After considerable pressure upon politicians by journalists, editors, writers, non-governmental freespeech organizations and public opinion, the British government announced a plan to carry out the necessary reforms by the 2011/12 parliamentary session [McAthy, Government to lead libel reform... (9 July 2010)]. A Draft Defamation Bill was first published in March 2011. This part sets out to summarize the main elements of the 2009-2012 reforms to defamation law in the English jurisdiction. Detailed information on this subject can be found in the article London, Libel Capital No Longer?: The Draft Defamation Act 2011 and the Future of Libel Tourism by Thomas Sanchez.

At the beginning, it is worth mentioning that the topic of libel tourism was extremely vivid across the broad spectrum of British print media. For example, the columnist Frances Gibb, writing for "The Times" stated in her article It's official London is the libel capital of the world that "libel tourism is flourishing and London is the hottest destination" (24 November 2009). While Jo Glanville pointed out in "The Guardian" that Our libel laws shame us (10 November 2009). Recently, press in the UK carried stories about the Draft Defamation Bill. For example, "Defamation 
Bill intended to kill off libel tourism" was announced by Oliver Wright and Rob Hastings in "The Independent" when the Bill was published on 15 March 2011.

Concern over libel reform was further expressed by two interest groups: Index on Censorship and English PEN. They decided to form an Inquiry Committee to write a report on the impact of English libel laws on freedom of expression entitled Free Speech Is Not For Sale: The Impact of English Libel Law on Freedom of Expression (published in November 2009). It was concluded in the report that [English PEN \& Index on Censorship, Free Speech...]:

English libel law has a negative impact on freedom of expression, both in the UK and around the world. Freedom of expression is a fundamental human right, and should only be limited in special circumstances. Yet English libel law imposes unnecessary and disproportionate restrictions on free speech.

Therefore, to restore the balance between freedom of expression and reputation, the report recommended 10 necessary changes regarding libel law. It is noteworthy that in this report, two recommendations significantly tackled the contributing factors to libel tourism. First and foremost, it was required that the "Duke of Brunswick rule" should be abolished - both Index on Censorship and English PEN supported the introduction of a single publication rule. Second, no case should be heard in an English jurisdiction unless at least 10 per cent of copies of the relevant publication have been circulated in England and Wales [English PEN \& Index on Censorship, Free Speech...]. Moreover, the report required the claimant to demonstrate damage and falsity; damages should be capped at $£ 10,000$; a libel tribunal should be established as a low-cost forum for hearings; the public interest defense should be strengthened; the definition of fair comment should be expanded; interactive online services and interactive chat should be exempt from liability; large and medium-sized corporate bodies and associations should be exempt from libel law unless they can be proven of malicious falsehood; base costs should be capped and success fees and "After the Event" (ATE) insurance premiums should be made non-recoverable [English PEN \& Index on Censorship, Free Speech...]. That was the announcement of the upcoming changes.

Finally, concerned about the risk arising from libel tourism, three charities English PEN and Index on Censorship with Sense About Science - came together and launched in 2009 a national campaign for the reform of current legislation, known as the Libel Reform Campaign. In the leaflet promoting the campaign titled "Reforming libel. What must a Defamation Bill achieve?" major recommendations were in fact repeated from the previous report [Libel Reform Campaign, Reforming libel...]. There was also a proposal to simplify and strengthen existing defenses such as statutory and qualified privilege. Additionally, journalists, editors, writers, legal experts and others asked the public to sign a petition supporting the reform of the libel laws. 
Dating back to February 2010, the Culture, Media and Sport Select Committee, appointed by the House of Commons, published the report Press standards, privacy and libel that identified some "problems with existing defamation law in the context of a wider look at press standards" [House of Commons, Defamation Bill (HL)]. Hence, during the 2010 General Election campaign, the ideas of libel laws' improvements appeared on the political agenda. As indicated by The Libel Reform Campaign, each major political party in its manifesto added reference to the law of libel [Libel Reform Campaign, Reforming libel...].

Taking the initiative to formulate specific reforms, Lord Lester of Herne Hill, a member of the Liberal Democrats, introduced into the House of Lords the Draft Defamation Bill. I consider this to be the beginning of a process which, in a reasonable way, deals with the phenomenon of libel tourism. Among other things, the Bill deals with: defenses including defense of responsible publication on a matter of public interest (clause 1); substantial harm requirement (clause 12); reversal of the multiple publication rule (clause 10); trial by jury (clause 14\&15) [House of Commons, Defamation Bill (HL)]. These recommendations have been taken into account by the Ministry of Justice which is formulating the provisions in the draft Bill [Draft Defamation Bill: Consultation Paper]. From journalists' perspective, Lord Lester's Defamation Bill was an important step forward to provide a better balance between protection to reputation and press freedom.

In January 2011, Deputy Prime Minister and Liberal Democrat leader Nick Clegg announced the intention to introduce a Draft Defamation Bill in the coming spring. In his Parliamentary speech on restoring Britain's civil liberties, he acknowledged the chilling effect of the current UK defamation law, including the phenomenon of libel tourism [Clegg, Restoring British liberties]:

I argued that English libel laws are having a chilling effect on scientific debate and investigative journalism. (...) It is simply not right when academics and journalists are effectively bullied into silence by the prospect of costly legal battles with wealthy individuals and big businesses. Nor should foreign claimants be able to exploit these laws, bringing cases against foreign defendants here to our courts - even if the connection with England is tenuous.

There was a very important event on March 15, 2011, including the Ministry of Justice presentation of the draft legislation; known as Draft Defamation Act 2011 [Sanchez 2001: 496]. It was further accompanied by a consultation paper and explanatory notes. Finally, in 2013, the Defamation Bill received Royal Assent on 25 April, and become the Defamation Act 2013. The Act contains fifteen clauses: requirement of serious harm; defense of truth; defense of honest opinion; publication on a matter of public interest; operators of websites; peer-reviewed statements in scientific or academic journals, etc.; reports, etc. protected by privilege; single publication rule; action against a person not domiciled in the UK or a Member State, etc.; action against 
a person who was not the author, editor, etc.; trial to be without a jury unless the court orders otherwise; power of court to order a summary of its judgment to be published; removal, etc. of statements, order to remove statement or cease distribution, etc., special damage, general provisions; meaning of "publish" and "statement".

According to Thomas Sanchez, the Act's procedural clauses bring English jurisdiction closer with other jurisdictions and, thereby eliminate potential libel tourism cases [2010: 495]. Section 9 states that: "a court does not have jurisdiction to hear and determine an action to which this section applies unless the court is satisfied that, of all the places in which the statement complained of has been published, England and Wales is clearly the most appropriate place in which to bring an action in respect of the statement" Moreover, section 8 of the Act abolished the Duke of Brunswick rule and instead, a single publication rule has been introduced. I conclude that it will lead to better protection of press freedom. However, reforms do not go as far it had been supposed. For example, the changes in the Act do not consider repealing the presumptions of falsity, which would remove the burden of proof from journalists. A new statutory defense of "truth" maintains the burden of proving the truth of an allegation on the defendant. As previously mentioned, this seriously comprises the protection of confidential sources. The current situation presents a dilemma for journalists: when the burden of proof lies on the journalists, under the pressure to verify that the they made allegation is true, they must either disclose their sources or face legal sanctions.

The Act came into force at the end of 2013. Despite best efforts, it is too early to foresee the results of these reforms, how long they will take, and whether they would actually be an important step forward in ending the chilling effect of libel tourism. ${ }^{6}$ However, I genuinely believe that this article has provided a useful framework to discuss the phenomenon of libel tourism further and is a starting point to continue empirical study on this issue. Moreover, this article should encourage policy makers to plan further concentrated actions to tackle libel tourism. In the light of my research, I would like to propose the following recommendations to allay this problem:

- Definitions: the Act contains a number of different concepts to ensure the free flow of information. However, in order to have more precise categories as tools for dealing with libel tourism, it is important to define proposed measures more precisely, such as: substantial harm.

- Training for journalists: one problem that I have found while researching this article is a lack of information and awareness among journalists and editors about libel laws in case of a possible lawsuit. It is therefore essential to train journalists particularly in libel law. Workshops and conferences should be held to increase the body of knowledge on libel law in general. Many journalists are not aware of the problem of libel tourism.

${ }^{6}$ Unfortunately, the fact that this article has been completed on 4 January 2014 prevents me from discussing in more detail events occurring in the present that are related to libel law reform. 
- Lobbying for harmonization of libel laws is needed at a national, European and international level. The ultimate purpose is to overcome the obstacles arising from the diversity in the national legal systems. It is important to underline that the three levels are complementary and not substitutes, despite the fact they have come to be considered as incompatible.

- Prevention of libel: changes should begin inside the newsroom. Specific references should be made to preventive measures, with a view to ensure higher professional standards. The best journalism practices should be strongly supported.

These recommendations are aimed to support safe, quality based journalism able to be involved in investigative work across borders. The lists contains some of the good practices that should allow journalists to publish their articles without fear of libel tourism.

\section{CONCLUSIONS}

England and Wales, through all "claimant friendly" elements mentioned above, were for a long time a favored destination for plaintiffs looking to engage in libel tourism. As technology evolves and communication is globalizing, the English libel system had enabled many foreign claimants to bring a defamation action outside their own country of residence, despite having no connection to an English forum. As a consequence, such laws were restricting freedom of expression on an incomparable global scale. After reading the theory written about the subject, I understand that there is indeed something dangerous about the phenomenon. As a consequence, the journalists may get sued in England, even if they do not direct their article to the English market. What is more, in trying to avoid possible problems regarding being brought before a foreign court, journalists might simply resign from writing on controversial topics. This would sooner or later limit freedom of expression and citizens' access to information.

There is no doubt that libel tourism is a global phenomenon. Plaintiff-friendly English libel laws had enforced major restrictions on free speech and this has not only affected English journalists, but also had an impact on international media. English libel judgments have the potential to chill speech in the United States and European democracies where the constitutional right to freedom of speech and freedom of press enjoys higher priority than protection of reputation of its citizens. Therefore, we may venture to say that the differences between national regulations on libel cause that the suing party prefers to bring a lawsuit in a country where press law is more strict. That is why libel law reform has become the subject of an intense debate not only in the United Kingdom, but also abroad [Staveley-O'Carroll 2009: 268]. Lack of any actions causes that phenomena such as globalization and growing importance of the Internet only make the risk of spreading "libel tourism" even larger. 


\section{LIST OF CASES}

Philadelphia Newspapers Inc v. Hepps [1986].

Liberace v. Daily Mirror Newspapers, "The Times", 18 June 1959.

Steele v. McDonald, 202 S.W.3d 926 (Tex. App. - Waco 2006, no pet.).

Belt v. Lawes [1882] 51 LJQB 359 at 361.

Gorman v. Mudd [1992] CA Transcript 1076 (unreported case, Court of Appeal, October 15, 1992).

Rantzen v. Mirror Group Newspapers [1986] Ltd [1994] QB 670.

Turkington v. Times Newspapers Ltd [1998] NI 358.

John v. MGN Ltd [1997] CA.

Kiam v. MGN Ltd [2002] 2 All ER 219.

Duke of Brunswick v. Harmer [1849] 14 QB 185.

Loutchansky v. Times Newspapers Ltd [2001] 3 WLR 404.

Kroch v. Rossell [1937] 1 All E.R. 725.

Berezovsky v. Michaels [2000] 1 WLR 1004.

Shevill v. Presse Alliance SA (Case C-68/93) [1995] 2 A.C. 18.

Polanski v. Condé Nast Publications Ltd. [2003] EWCA Civ 1573.

Dombrowski v. Pfister [1965] 380 U.S. 479.

Ehrenfeld v. Mahfouz [2005] EWHC 1156 (QB).

\section{BIBLIOGRAPHY}

Abrams, F. 2009. Through the Looking Glass, "Index on Censorship for Free Expression”, http://www. indexoncensorship.org/2009/06/through-the-looking-glass/ (access 06.11.2011).

Bennett, W. 2010. The Current State of Defamation Law In England and Wales, January, http://www. europarl.europa.eu/document/activities/cont/201002/20100204ATT68476/20100204ATT68476EN. pdf (access 06.11.2011).

Be Reasonable, London "The Times" May 2005, http://www.timesonline.co.uk/tol/comment/leading_article/ article524052.ece (access 06.11.2011).

Bin Mahfouz Information (N.D.), http://www.binmahfouz.info/faqs_1.html (access 05.02.2012).

Carvajal, D. 2010. Britain, a destination for 'libel tourism', “The New York Times", http://www.nytimes. com/2008/01/20/technology/20iht-libel21.1.9346664.html (access 14.12.2010).

Clegg, N. 2011. Restoring British liberties, "Liberal Democrats", http://www.nickclegg.com/nccom_news details.aspx?title=Nick_Clegg\%3a_Restoring_British_liberties\&pPK=7781a555-f93b-4818-b08ff6382841dc89 (access 25.03.2011).

CNN Larry King Live, 2002. CNN.com, http://transcripts.cnn.com/TRANSCRIPTS/0208/12/lk1.00.html (access 12.03.2012).

Collier, J. G. 2001. Conflict of Laws, Cambridge: Cambridge University Press, p. 3.

Conzes, C. 2005. Polanski wins libel case against Vanity Fair, “The Guardian”, http://www.guardian.co.uk/ media/2005/jul/22/pressandpublishing.generalelection2005 (access 14.12.2010).

Courts and Legal Services Act 1990 (c.41), "Legislation.gov.uk" (N.D.), http://www.legislation.gov.uk/ ukpga/1990/41/contents (access 05.02.2012).

Dunlop, R. (N.D.). Case analysis: Article 10, the Reynolds Test and the Rule in the Duke of Brunswick's case: the decision in Times Newspaper Ltd v the United Kingdom, http://www.39essex.com/docs/ articles/RDL_Times_v_UK.pdf (access 06.11.2011).

EC Convention on Jurisdiction and the Enforcement of Judgments in Civil and Commercial Matters, 1968, European Union (N.D.), http://www.jus.uio.no/lm/ec.jurisdiction.enforcement.judgements.civil.commercial.matters.convention.brussels.1968/doc.html (access 15.03.2012). 
Godfather of the Kremlin?, “Forbes” December 1996, http://www.forbes.com/forbes/1996/1230/5815090a. $\mathrm{html}$ (access 07.11.2011).

Greenslade, R. 2009. The meaning of 'fruit': how the Daily Mirror libeled Liberace, "Daily Mirror", http:// www.guardian.co.uk/media/greenslade/2009/may/26/daily-mirror-medialaw (access 14.12.2010).

House of Commons. Culture, Media and Sport Committee, 2010. Press standards, privacy and libel, Second Report of Session 2009-10, http://www.publications.parliament.uk/pa/cm200910/cmselect/ cmcumeds/362/36206.htm (access 06.11.2011).

House of Commons, Parliament UK, 2010. Defamation Bill [HL], http:/www.publications.parliament.uk/ $\mathrm{pa} / \mathrm{ld} 201011 / \mathrm{ldbills} / 003 / 11003$. i-ii.html (access 05.02.2012).

Index on Censorship/English Pen, 2009. Parliamentary briefing: free speech libel law and super-injunctions, http://blog.indexoncensorship.org/wp-content/uploads/2009/10/freedomofspeechbriefing.pdf (access 06.11.2011).

Libel Law Reform Campaign (N.D.), http://www.libelreform.org/ (access 12.03.2012).

Libel Reform Campaign, (N.D.). Reforming libel. What must a Defamation Bill achieve?, www.libelreform. org (access 05.02.2012).

McAthy, R. 2010. Government to lead libel reform with new Defamation Bill, “Journalism.co.uk.”, http:// www.journalism.co.uk/news/government-to-lead-libel-reform-with-new-defamation-bill/s2/a539552/ (access 15.12.2010).

Ministry of Justice, 2011. Draft Defamation Bill: Consultation Paper CP3/11, "Justice.gov.uk", http:// www.justice.gov.uk/consultations/draft-defamation-bill_access 05.02.2012).

Ministry of Justice, 2010. Report of the Libel Working Group, “Justice.gov.uk”, http://webarchive.nationalarchives.gov.uk/20110322191207/http:/www.justice.gov.uk/publications/docs/libel-working-group-report.pdf (access 02.02.2010).

Owen, R. 2001. Essential Tort Law, Routledge-Cavendish, London, p. 130.

Parliament UK, 2009. Memorandum, http://www.publications.parlaiment.uk/pa/cm200910/cmselect/cmcumeds/memo/press/ucps4502.htm (access 16.01.2012).

Partlett, D., McDonald, B. 2011. International publications and protection of reputation: a margin of appreciation but not subservience? "Alabama Law Review”, vol. 62(3), http://www.law.ua.edu/ pubs//rarticles/Volume\%2062/Issue\%203/PARTLETT_MCDONALD-International_Publications. pdf (access 20.02.2012).

Rayner, G. 2010. How libel tourism became an 'embarrassment'to Britain's reputation. "The Telegraph", http://www.telegraph.co.uk/news/7301403/How-libel-tourism-became-an-embarrassment-to-Britains-reputation.html (access 11.12.2010).

Sanchez, T. 2011. London, Libel Capital No Longer?: The Draft Defamation Act 2011 and the Future of Libel Tourism, University of New Hampshire Law Review, vol. 9(3), http://law.unh.edu/assets/pdf/ unh-law-review-vol-09-no3-sanchez.pdf (access 04.02.2012).

Schauer, F. 1978. Fear, Risk and the First Amendment: Unraveling the Chilling Effect, "Faculty Publications", http://scholarship.law.wm.edu/facpubs/879 (access 25.02.2012).

Shapiro, F. R. 2006. The Yale Book of Quotations, Yale University Press, p. 102.

Slapper, G., Kelly, D. 2011. The English legal system 2011-2012, $12^{\text {th }}$ edition, Routledge-Cavendish, London, p. 491.

Smet, S. 2010. Freedom of Expression and the Right to Reputation: Human Rights in Conflict, "American University International Law Review", vol. 26(1), pp. 183-236.

Staveley-O'Carroll, S. 2009. Libel tourism laws: spoiling the holiday and saving the first amendment?, "New York University Journal of Law \& Liberty", vol. 4, p. 252, http://www.law.nyu.edu/ecm_dlv1/ groups/public/@nyu_law_website_journals_journal_of_law_and_liberty/documents/documents/ ecm_pro_062709.pdf (access 04.02.2012).

Sutter, G. 2009. Defamation, [in:] Media Law and Practice, D. Goldberg, G. Sutter and I. Walden (eds.), Oxford University Press, Oxford. p. 491.

Taylor, D. C. 2010. Libel tourism: Protecting Authors and Preserving Comity, "The Georgetown Law Journal”, vol. 99, p. 189, http://georgetownlawjournal.org/files/pdf/99-1/Taylor.pdf (access 06.11.2011). 
The Coroners and Justice Act 2009 (c. 25), "Legislation.gov.uk" (N.D.), http://www.legislation.gov.uk/ ukpga/2009/25/contents (access 05.01.2012).

U.S. Congress 2010. Securing the Protection of Our Enduring and Established Constitutional Heritage Act, Pub. L. No. 111-223, 124 Stat. 2380, 2380, http://www.govtrack.us/congress/bills/111/hr2765 (access 02.02.2012).

Watrous, G. D. 1899. The Newspaper Before the Law, Faculty Scholarship Series. Paper 3983, http:// digitalcommons.law.yale.edu/fss_papers/3983 (access 06.11.2011).

White, A. 2008. To tell you the truth: the Ethical Journalism Initiative, International Federation of Journalists, Brussels, p. 134.

Williams, A. 1997. England and Wales, [in:] International Media Liability: Civil Liability in the Information Age, Christian Campbell (ed.), John Wiley \& Sons, p. 107.

Windon, J. 2010. Fee Shifting in Libel Litigation: How the American Approach to Costs Allocation Inhibits the Achievement of Libel Law's Substantive Goals, "J. Int'1 Media \& Entertainment Law", vol. 3(1), http://www.swlaw.edu/pdfs/jimel/3_1_windon.pdf (access 06.11.2011).

\section{ABOUT THE AUTHOR}

Olga Bogdańska is a $\mathrm{PhD}$ student in the Interdisciplinary Doctoral Program in the Humanities, University of Łódź. Her research interests are in the British mass media and the representations of warfare including both fictional and nonfictional portrayals and the intersection of these genres. She received her M.A. in the field of International Relations from the Faculty of International and Political Studies (2012) and B.A. from the Department of Journalism and Social Communication (2013). She completed her internship at the International/European Federation of Journalists in Belgium. 